See discussions, stats, and author profiles for this publication at: https://www.researchgate.net/publication/235858078

\title{
Sediment size and deposition characteristics in Malaysian urban concrete drains - a case study of Kuching City
}

Article in Urban Water Journal · January 2014

DOI: 10.1080/1573062x.2012.750371

CITATIONS

14

3 authors:

Charles Hin Joo Bong

University Malaysia Sarawak

36 PUBLICATIONS 193 CITATIONS

SEE PROFILE

28. Aminuddin Ab Ghani

Universiti Sains Malaysia

225 PUBLICATIONS 2,392 CITATIONS

SEE PROFILE

Some of the authors of this publication are also working on these related projects:

Bioretention View project

The Influence of Soil Characteristics to the Hydraulic Performance in Bioretention System View project
READS

285

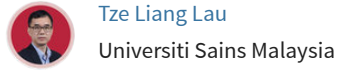

68 PUBLICATIONS 204 CITATIONS

SEE PROFILE 
This article was downloaded by: [Universiti Sains Malaysia]

On: 05 March 2013, At: 01:01

Publisher: Taylor \& Francis

Informa Ltd Registered in England and Wales Registered Number: 1072954 Registered office: Mortimer House, 37-41 Mortimer Street, London W1T 3J H, UK

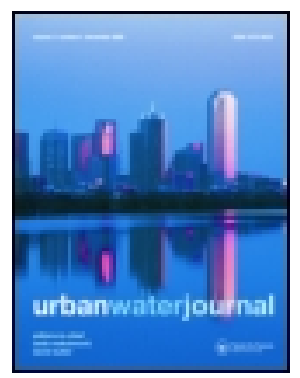

\title{
Urban Water J ournal
}

Publication details, including instructions for authors and subscription information:

http:// www. tandfonline.com/loi/ nurw20

\section{Sediment size and deposition characteristics in Malaysian urban concrete drains - a case study of Kuching City}

\author{
Charles Hin J 00 Bong $^{a}$, Tze Liang Lau ${ }^{a} \&$ Aminuddin Ab. Ghani ${ }^{a}$ \\ ${ }^{a}$ River Engineering and Urban Drainage Research Centre (REDAC), Universiti Sains Malaysia, \\ Engineering Campus, Seri Ampangan, 14300, Nibong Tebal, Penang, Malaysia \\ Version of record first published: 05 Mar 2013.
}

To cite this article: Charles Hin J oo Bong, Tze Liang Lau \& Aminuddin Ab. Ghani (2013): Sediment size and deposition characteristics in Malaysian urban concrete drains - a case study of Kuching City, Urban Water J ournal, DOI: $10.1080 / 1573062 X .2012 .750371$

To link to this article: http:// dx.doi.org/ 10.1080/ 1573062X.2012.750371

\section{PLEASE SCROLL DOWN FOR ARTICLE}

Full terms and conditions of use: http://www.tandfonline.com/page/terms-and-conditions

This article may be used for research, teaching, and private study purposes. Any substantial or systematic reproduction, redistribution, reselling, loan, sub-licensing, systematic supply, or distribution in any form to anyone is expressly forbidden.

The publisher does not give any warranty express or implied or make any representation that the contents will be complete or accurate or up to date. The accuracy of any instructions, formulae, and drug doses should be independently verified with primary sources. The publisher shall not be liable for any loss, actions, claims, proceedings, demand, or costs or damages whatsoever or howsoever caused arising directly or indirectly in connection with or arising out of the use of this material. 
RESEARCH ARTICLE

\title{
Sediment size and deposition characteristics in Malaysian urban concrete drains - a case study of Kuching City
}

\author{
Charles Hin Joo Bong*, Tze Liang Lau and Aminuddin Ab. Ghani \\ River Engineering and Urban Drainage Research Centre (REDAC), Universiti Sains Malaysia, Engineering Campus, Seri Ampangan, \\ 14300 Nibong Tebal, Penang, Malaysia
}

(Received 20 June 2011; final version received 13 November 2012)

\begin{abstract}
This paper highlights the results of sediment size characteristics and deposition analysis on 24 sediment samples from urban concrete drains in Kuching City. Further sampling from surrounding urban towns outside Kuching City and Penang were done for comparison. Samples were collected randomly from three land-use types (residential, commercial and industrial). Sieve analysis results had shown that most of the total samples collected (51 out of 57) were predominantly sand, followed by gravel; while silt and clay were the minor components. Unimodal characteristics were observed in 46 samples while 11 samples showed bimodal characteristics. Of the total 46 unimodal samples, 39 showed non-uniform distribution with tendency to skew to the right. Due to this, the mode grain size with characteristic diameter $d_{45}$ is suggested as a much better representative size than the conventional median size $d_{50}$. Factors affecting sediment deposition characteristics in urban drains are also discussed.
\end{abstract}

Keywords: characteristic diameter; deposition; sediment; urban areas; urban drainage

\section{Introduction}

Sediment deposits in sewers had been known to have an adverse effect on the sewer system and the environment. The nature of sewer sediments was first defined systematically by Crabtree (1989). Sediments that enter sewer systems originate from rooftops, streets and highways, construction sites, commercial and industrial parking lots and runoff (Fan et al. 2003). Sediments in storm sewers are mainly inorganic and non-cohesive (Butler et al. 2003). As for combined sewers, it is widely accepted to have cohesive properties due to the presence of organic substances (Campisano et al. 2008). Studies on urban litter (Armitage and Rooseboom, 2000, Marais et al. 2004, Armitage, 2007) had classified sediment as secondary pollution and is of great concern as they could contain potentially dangerous concentrations of heavy metals, nutrients or pesticides of human origin. This high concentration of pollutants could be released during the erosion of sediment depositions (Ashley et al. 1992a). Losses of hydraulic capacity due to sediment deposition have been identified as one of the factors of flash flooding in urban areas (Ab. Ghani et al. 2008, Liew et al. 2012, Rodríguez et al. 2012). Under given conditions, a substantial increase in sediment depth (from $2 \%$ to $10 \%$ ) resulted in a $10 \%$ to $20 \%$ reduction of full sewer discharge capacity relative to a clean sewer (Banasiak, 2008). While structured best management practices (BMPs) provide some level of control, many of the devices rely on settling of sediment and their effectiveness is largely dependent on the range of particle sizes in storm water runoff (Selbig and Fienen, 2012).

In Malaysia, separate networks of storm water and sanitary sewer are used. The design of urban storm water drains in Malaysia follows a manual known as "Urban Storm Water Management Manual for Malaysia" (DID, 2000, 2012). To reduce sediment deposition in an urban open storm concrete drain, a minimum constant selfcleansing velocity of $0.9 \mathrm{~m} / \mathrm{s}$ had been recommended by the Department of Irrigation and Drainage (DID), Malaysia (Ab. Ghani et al. 2000). The adoption of a constant minimum value however does not take into account the characteristics of the sediment and the hydraulic aspect of the channel (Butler et al. 2003). Vongvisessomjai et al. (2010) provides a review on the minimum value for velocity and shear stress adopted by various countries for a self-cleansing design for sewers.

Various approaches and suggestions exist in the literature to choose the characteristic diameter to be the representative particle size for a sediment distribution (Tranckner et al. 2008). However, choosing a robust characteristic diameter for a given sediment sample distribution still remains an issue. A robust characteristic

*Corresponding author. Email: bhjcharles@feng.unimas.my

(C) 2013 Taylor \& Francis 